\begin{tabular}{|l|l|l||}
\hline \multicolumn{2}{|c|}{ PublisherInfo } \\
\hline \hline PublisherName & $:$ & BioMed Central \\
\hline \hline PublisherLocation & $:$ & London \\
\hline \hline PublisherImprintName & $:$ & BioMed Central \\
\hline \hline
\end{tabular}

\title{
Gene discovery by stringent annotation
}

\begin{tabular}{|l|l|l||}
\hline \multicolumn{2}{|c|}{ ArticleInfo } \\
\hline \hline ArticleID & $:$ & 3999 \\
\hline \hline ArticleDOI & $:$ & $10.1186 /$ gb-spotlight-20010305-01 \\
\hline \hline ArticleCitationID & $:$ & spotlight-20010305-01 \\
\hline \hline ArticleSequenceNumber & $:$ & 70 \\
\hline \hline ArticleCategory & $:$ & Research news \\
\hline \hline ArticleFirstPage & $:$ & 1 \\
\hline \hline ArticleLastPage & $:$ & 2 \\
\hline \hline & & RegistrationDate : 2001-03-05 \\
ArticleHistory & $:$ & OnlineDate \\
\hline \hline ArticleCopyright & $:$ & BioMed Central Ltd2001-03-05 \\
\hline \hline ArticleGrants & $:$ & \\
\hline \hline ArticleContext & $:$ & 130592211 \\
\hline \hline
\end{tabular}




\section{Jonathan B Weitzman}

Email: jonathanweitzman@hotmail.com

In the March Nature Genetics, Gopal et al. describe a two-step approach to identify novel genes by combining stringent annotation with broad gene-prediction techniques (Nature Genetics 2001, 27:337-340). The first step involves identification of potential exons using the GENSCAN gene-finding program. In the second step, predicted genes are compared with all available gene and protein sequences, including expressed sequence tags (ESTs) from other organisms, at the protein level (in all six translation frames). The authors combined sequence comparisons with comparative protein structure modeling to confirm their results. Gopal et al. applied this method to analysis of the Drosophilagenome to validate the technique. Filtering of over 19,000 plausible Drosophila genes (of which 12,124 matched the original 13,601 annotated genes) led to the identification of 1,042 putative novel genes, which had not previously been annotated but had strong supporting evidence as real gene candidates. These prediction results should serve as a basis for future experimental confirmation.

\section{References}

1. Nature Genetics, [http://genetics.nature.com]

2. Finding the genes in genomic DNA.

3. Genome cross-referencing and XREFdb: implications for the identification and analysis of genes mutated in human disease.

4. The genome sequence of Drosophila melanogaster.

5. Drosophila melanogaster genome analysis, [http://genomes.rockefeller.edu/dm]

This PDF file was created after publication. 